\title{
Prognosis in human glioblastoma based on expression of ligand growth hormone-releasing hormone, pituitary-type growth hormone-releasing hormone receptor, its splicing variant receptors, EGF receptor and PTEN genes
}

\author{
Géza Mezey • Andrea Treszl • Andrew V. Schally • Normann L. Block • \\ Laura Vízkeleti · Alíz Juhász • Álmos Klekner · János Nagy • Margit Balázs • \\ Gábor Halmos • László Bognár
}

Received: 30 March 2014 / Accepted: 14 May 2014

(C) Springer-Verlag Berlin Heidelberg 2014

\begin{abstract}
Purpose Glioblastoma (GB) is the most frequent brain tumor. Despite recent improvement in therapeutic strategies, the prognosis of GB remains poor. Growth hormone-releasing hormone (GHRH) may act as a growth factor; antagonists of GHRH have been successfully applied for experimental treatment of different types of tumors. The expression profile of GHRH receptor, its main splice variant SV1 and GHRH have not been investigated in human GB tissue samples.

Methods We examined the expression of GHRH, fulllength pituitary-type GHRH receptor (pGHRHR), its functional splice variant SV1 and non-functional SV2 by RTPCR in 23 human GB specimens. Epidermal growth factor receptor (EGFR) and phosphatase and tensin homolog gene (PTEN) expression levels were also evaluated by quantitative RT-PCR. Correlations between clinico-pathological parameters and gene expressions were analyzed.
\end{abstract}

G. Mezey and A. Treszl contributed equally to this work.

G. Mezey · Á. Klekner · L. Bognár $(\bowtie)$

Department of Neurosurgery, University of Debrecen,

Nagyerdei krt. 98, Debrecen 4032, Hungary

e-mail: bognarl@dote.hu

\section{A. Treszl · A. Juhász $\cdot$ G. Halmos}

Department of Biopharmacy, University of Debrecen,

Nagyerdei krt. 98, Debrecen 4032, Hungary

e-mail: halmos.gabor@pharm.unideb.hu

\author{
A. V. Schally · N. L. Block · G. Halmos \\ Endocrine, Polypeptide and Cancer Institute and South Florida \\ Veterans Affairs Foundation for Research and Education, \\ Veterans Affairs Medical Center, Miami, FL 33125, USA \\ A. V. Schally $\cdot$ N. L. Block $\cdot$ G. Halmos \\ Department of Pathology, Miller School of Medicine, University \\ of Miami, Miami, FL 33101, USA
}

Results Expression of GHRH was found to be positive in $61.9 \%$ of samples. pGHRH receptor was not expressed in our sample set, while SV1 could be detected in $17.4 \%$ and SV2 in $8.6 \%$ of the GB tissues. In 65.2 and $78.3 \%$ of samples, significant EGFR over-expression or PTEN under-representation could be detected, respectively. In $47.8 \%$ of cases, EGFR up-regulation and PTEN down-regulation occurred together. Survival was significantly poorer in tumors lacking GHRH expression. This worse prognosis in GHRH negative group remained significant even if SV1 was also expressed.

Conclusion Our study shows that GHRH and SV1 genes expressed in human GB samples and their expression patterns are associated with poorer prognosis.

Keywords GHRH $\cdot$ pGHRHR $\cdot$ Splice variants $\cdot$ SV1 EGFR $\cdot$ PTEN $\cdot$ Human glioblastoma

A. V. Schally $\cdot$ N. L. Block $\cdot$ G. Halmos

Department of Medicine, Division of Hematology-Oncology,

Miller School of Medicine, University of Miami, Miami,

FL 33101, USA

L. Vízkeleti

Public Health Research Group of the Hungarian Academy

of Sciences, University of Debrecen, Nagyerdei krt. 98,

Debrecen 4032, Hungary

J. Nagy

Institute of Oncology, University of Debrecen, Nagyerdei krt. 98,

Debrecen 4032, Hungary

M. Balázs

Department of Preventive Medicine, University of Debrecen,

Nagyerdei krt. 98, Debrecen 4032, Hungary 


\section{Introduction}

Glioblastoma (GB) is the most frequent primary human brain tumor (Louis et al. 2007). Although recent therapeutic strategies have shown moderate effect on the overall survival time for patients with GB (Stupp et al. 2005), its prognosis remains poor because of the high infiltrating potential and the limited efficacy of surgical and oncological treatments. In the majority of the cases, GB emerged as primary GB without any clinical or histological evidence of a less malignant precursor lesion (secondary GB). In spite of numerous attempts to identify molecular prognostic factors, the relevant prognostic indicators still remain age, performance score and extent of surgical resection (Weller et al. 2009). In general, the invasive potential of GB highly restricts the efficacy of surgery, and the recently adopted combination of temozolamide chemotherapy and radiotherapy are neither specific nor selective for this type of tumor (Stupp et al. 2005).

The most common genetic abnormality in gliomagenesis is the activation of receptor tyrosine kinases (RTKs), specifically the aberrant expression of epidermal growth factor receptor (EGFR) (Cancer Genome Atlas Research Network 2008). In line with EGFR gene amplification events, there is an increase in intragenic in-frame deletion of exons 2-7 of the EGFR gene (Zhu et al. 2009). This mutated EGFR, known as EGFRv3, is a constitutively activated, ligandindependent receptor. In addition, the amplification of the EGFR locus leads to the co- and over-expression of wild type (wt) and v3 within the same cells (Zhu et al. 2009). However, the over-expression of wt EGFR or v3 alone is not a transforming event in adult brain tissues (Zhu et al. 2009). An extensive molecular characterization of human GBs revealed a finite number of genetic aberration in which RTKs are activated concomitantly with the loss of tumor suppressor gene functions, such as those encoded by phosphatase and tensin homolog gene (PTEN). PTEN is located on chromosome $10 \mathrm{q}$ which is the most frequently lost chromosome in GBs, occurring in up to $85 \%$ of cases (Steck et al. 1997; Li et al. 1997; Knobbe et al. 2002). Recently, it has been shown that loss of PTEN in GB leads to the development of resistance to therapy with EGFR kinase inhibitor agents (Mellinghoff et al. 2005).

The gene for pituitary-type growth hormone-releasing hormone receptor (pGHRHR) is located on chromosome $7 p$, near EGFR. The presence of growth hormone-releasing hormone (GHRH) has been shown to act as a growth factor in various cancers (Schally et al. 2008; Schally and Halmos 2012). Moreover, antagonists of GHRH have been applied successfully for the treatment of different types of tumors, including malignant gliomas (Schally et al. 2008; Schally and Halmos 2012; Schally and Varga 1999, 2006; Pozsgai et al. 2010; Jaszberenyi et al. 2013). However, the expression profiles of GHRH receptor and its main splice variant, SV1 has not been investigated in human GB tissue samples. In this study, we examined the mRNA expression of GHRH, its two functional receptors, pGHRHR and SV1, and non-functional splice variant SV2 in 23 human GB tissues. We also determined the EGFR and PTEN expression levels in our sample set. Since detailed clinical history with complete follow-up was also available, correlations could be analyzed between clinico-pathological parameters and gene expressions.

\section{Materials and methods}

Tissue samples

Twenty-six tissue samples (23 glioblastomas and 3 peritumoral tissues) were collected during neurosurgical operations in the Department of Neurosurgery, University of Debrecen, Hungary. The samples were frozen immediately after removal in liquid nitrogen and stored at $-80{ }^{\circ} \mathrm{C}$ until processing. Sections were cut from the same samples for histological analysis and genetic investigations. Lesions were diagnosed on the basis of formalin-fixed paraffinembedded (FFPE) tissue sections by hematoxylin-eosin staining and by additional immunohistochemistry. Classification of tumors was based on the World Health Organization International Classification of Tumours 2007 (Louis et al. 2007). The local institutional ethics committee approved the collection and use of these specimens for the current study and informed consent was obtained from all patients.

RNA extraction and RT-PCR for detecting GHRH, pGHRHR, SV1 and SV2

Frozen tissue samples were incubated overnight at $-20{ }^{\circ} \mathrm{C}$ in RNAlater Ice solution (Qiagen, $\mathrm{GmbH}$, Germany). RNeasy mini kit (Qiagen, GmbH, Germany) was used to isolate total RNA from tissue samples. RNA quantity and quality were determined by NanoDrop ND-1000 UV-Vis Spectrophotometer (NanoDrop Technologies, Wilmington, DE) and $1 \%$ TAE agarose gel. Two hundred fifty nanograms of RNA from each sample were reverse transcribed into cDNA by QuantiTect Reverse Transcription kit (Qiagen) in a final volume of $20 \mu \mathrm{l}$. The integrity of cDNA was tested by RT-PCR for $\beta$-actin (ACTB). Gene-specific primers for pGHRH-R (sense: 5'-CACGTCTTCTGCGTGTTGAG-3', antisense: 5'-GCATCTCCTCTGCTGCTTGT-3') and SV1 (sense: 5'-GGAGTTGTGGCTAGAGAG-3', antisense: 5'-GCATAGAACAGTGGAGAAG-3') were designed with the primer3_www.cgi v0.2 program (Rozen and Skaletsky 2000), and primers for GHRH and ACTB were described 

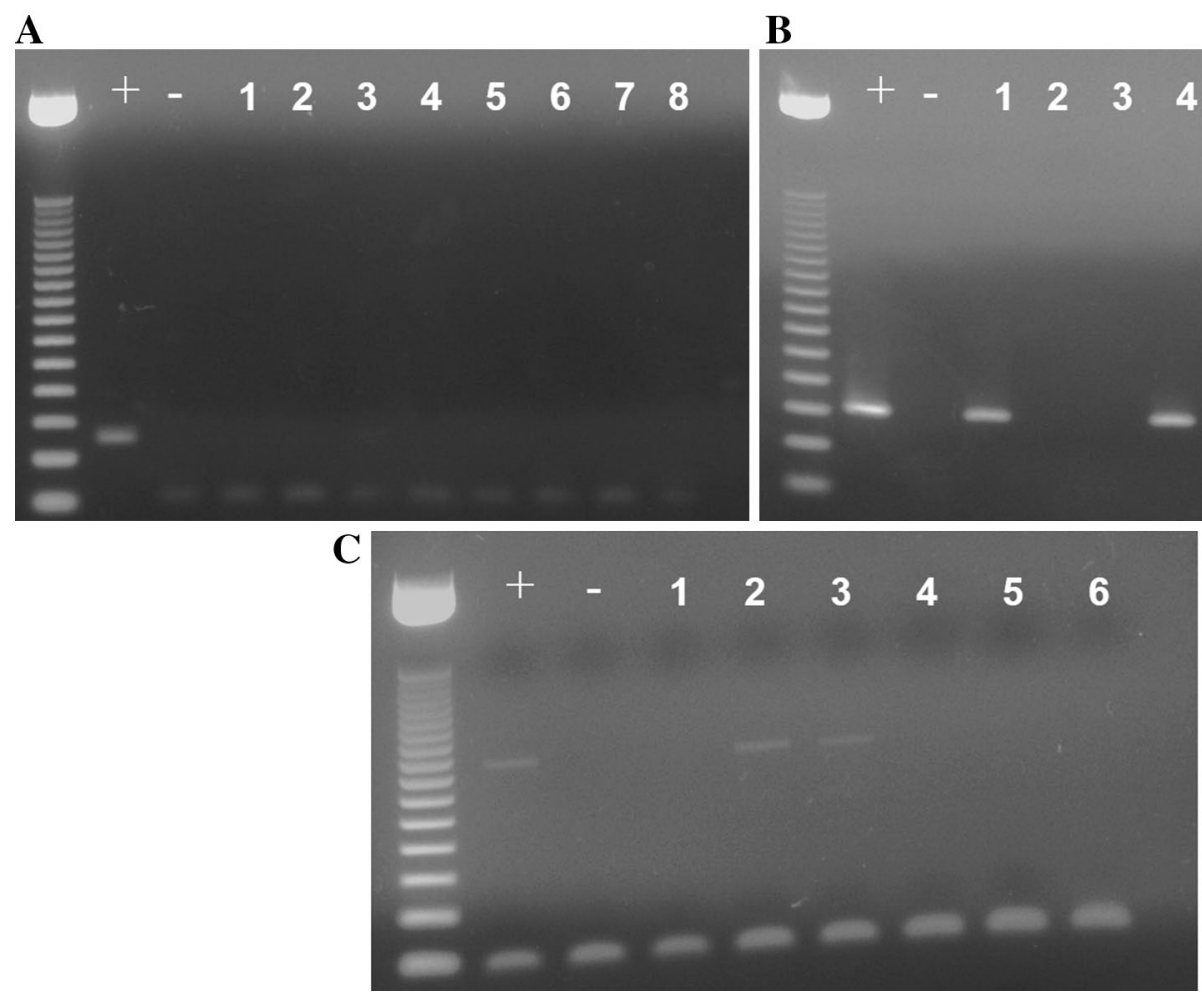

Fig. 1 GHRH ligand and receptor expressions in GB samples. Representative gel photos of mRNA expression of a pGHRHR, b GHRH, c splicing variant, SV1; + positive control (human pituitary), - negative control; No. 1-8 GB samples

previously (Havt et al. 2005; Øvstebø et al. 2003). In all RT-PCR reactions, $1 \mu l$ of cDNA was amplified in a $25 \mu \mathrm{l}$ solution containing $1.5 \mathrm{mM} \mathrm{MgCl} 2,1 \times$ PCR buffer (Fermentas, Germany), $0.3 \mathrm{mM}$ of each deoxynucleotide (Promega, Germany), 1 unit of TrueStart HotStart DNA polymerase (Fermentas) and $0.25 \mu \mathrm{M}$ of each primer. Samples were denatured for $3 \mathrm{~min}$ at $95{ }^{\circ} \mathrm{C}$, then subjected to 30 (ACTB) or 40 cycles of $95{ }^{\circ} \mathrm{C}$ for $45 \mathrm{~s}, 54{ }^{\circ} \mathrm{C}$ (SV1), $59{ }^{\circ} \mathrm{C}(\mathrm{SV} 2) 64{ }^{\circ} \mathrm{C}(\mathrm{GHRH})$ or $67{ }^{\circ} \mathrm{C}$ (pGHRHR) for $30 \mathrm{~s}$, then $72{ }^{\circ} \mathrm{C}$ for $1.5 \mathrm{~min}$ with a final extension of $10 \mathrm{~min}$ at $72{ }^{\circ} \mathrm{C} ; 10 \mu \mathrm{l}$ of each amplification reaction was electrophoretically separated on $1.5 \%$ agarose gel, stained with ethidium bromide, and visualized under UV light (Fig. 1).

\section{Quantitative RT-PCR for detecting EGFR and PTEN}

Six hundred nanogram of RNA from each sample was translated into cDNA applying High Capacity cDNA Reverse Transcription kit (Applied Biosystems, CA, USA) according to the manufacturer's instructions. SYBR Green Premix Ex Taq-based assay was used to determine the mRNA expression level of EGFR and PTEN genes (Takara Bio Inc., Japan). For the analysis, the following primers were used, each in $0.25 \mu \mathrm{M}$ final concentration: EGFR (forward: 5'-CTC AGC CAC CCA TAT GTA CC-3'; reverse: $5^{\prime}$-CGT CCA TGT CTT CTT CAT CC-3'),
PTEN (forward: 5'-AGC ATC ACC ATT CTT TGC TG-3'; reverse: 5'-ACC ACA GCC ATC GTT ATG AA-3') and GAPDH (forward: 5'-CAG TCA ACG GAT TTG GTC GT-3'; reverse: 5'-TTG ATT TTG GAG GGA TCT CG-3'). Each reaction contained $15 \mathrm{ng}$ cDNA and was run in triplicate on $\mathrm{M} \times 3005 \mathrm{P}^{\mathrm{TM}}$ real-time $\mathrm{PCR}$ system (Agilent Technologies, USA) with the following thermal profile: activation at $95{ }^{\circ} \mathrm{C}$ for $1 \mathrm{~min}$; 40 cycles of amplification at $95{ }^{\circ} \mathrm{C}$ for $1 \mathrm{~min}$, at $55{ }^{\circ} \mathrm{C}(\mathrm{GAPDH}), 58{ }^{\circ} \mathrm{C}$ (EGFR) or $60{ }^{\circ} \mathrm{C}$ (PTEN) for $30 \mathrm{~s}$ followed by $72{ }^{\circ} \mathrm{C}$ for $1 \mathrm{~min}$. Melting curve analysis was also performed in each case. Fold changes in gene expression were calculated by the $\Delta \Delta \mathrm{Ct}$ method (Livak and Schmittgen 2001) using GAPDH as internal control and peritumoral tissue sample as calibrator.

Statistical analysis

For statistical analysis, the IBM SPSS Statistics 19 software (IBM Corporation, USA) was used. In cases of EGFR and PTEN, more than twofold change in the gene expression level was considered as gene down- or up-regulation. On the basis of the Kolmogorov-Smirnov test, the distribution of EGFR expression data is significantly different from a normal one so nonparametric tests were applied to compare the mRNA expression levels of EGFR (Mann-Whitney U test), PTEN (independent samples median test) genes and 
the expression profiles of GHRH, SV1 and clinico-pathological data. Kaplan-Meier method with log rank (MantelCox) test was used for survival analysis. Differences with $p<0.05$ were considered statistically significant.

\section{Results}

Clinical course of the patients

Twenty-three patients suffering from primary GB were operated in our department during the period of November 2005 and November 2008. Samples from their resected solid tumors were studied. The largest tumor diameter was $>3$ centimeters in all cases. In case of 15 patients, the operation was performed at the first recognition of the tumor. After surgery, standard postoperative treatment was initiated. The postoperative treatment was canceled in four cases because of the rapid progression of the tumor and, in one case, because of non-compliance by the patient. Eight of the 23 patients had previous surgery and received regular postoperative treatment for proven GB histology. In these cases, samples were collected at the reoperation of the tumor recurrence. In four of these cases, we also had samples from the first operation. In 3 cases, we obtained peritumoral tissues, which required removal to facilitate approach to the tumors themselves. These tissues were used for calibration in subsequently measuring EGFR and PTEN expression levels.

The mean age of the patients sampled was 59.8 years \pm 2.2 SE (range 37-78 years), with 14:9 ratio of female to male. The follow-up lasted until the death of the last patient (June 2011). Mean overall survival was 536.3 days \pm 107.0 SE $(n=19)$ from diagnosis, and mean survival from sampling was 411.3 days $\pm 90.3 \mathrm{SE}(n=23)$. The four operated and later reoperated patients were calculated, of course, as one patient in the relevant statistics. All of the patients died because of tumor progression. Clinicopathological data of patients are summarized in Table 1.

Expression of pGHRHR, SV1, SV2 and GHRH in human GB samples

Pituitary-type GHRH (pGHRHR) receptor was not expressed in our sample set while SV1 could be detected in $17.4 \%$ of the tissues (4 out of 23). Another-presumably non-functional-splice variant, SV2, could be detected in 2 samples $(8.6 \%)$.

To examine the possible autocrine and paracrine effect of the natural ligand, the expression of GHRH was also determined and found to be positive in 14 samples out of $23(61.9 \%)$. Only one sample expressed both the ligand GHRH and receptor SV1. Among the 9 of 23 GHRH negative samples, three were positive for SV1. Constellations of pGHRHR, SV1, SV2 and GHRH expressions of samples were detailed in Table 2.

\section{Expression levels of EGFR and PTEN}

The expression levels of EGFR and PTEN genes were presented as normalized data as it was written in the "Materials and methods" section. In 15 of 23 samples (65.2\%), significant EGFR over-expression could be detected, and 18 samples showed significant PTEN gene under-representation $(78.3 \%)$. In case of 11 patients $(47.8 \%)$, EGFR up-regulation was accompanied by PTEN down-regulation. The results of gene expression analyses are presented in Table 3.

Expression profiles of samples from the same patient prior and after therapy

In case of 4 patients, we had the opportunity to take tumor samples both at the first operation and at surgery for recurrence. In 3 of these cases, GHRH was present in the initial tumor but could not be detected in the tumor tissue from the recurrence. SV1 was present in only one tumor at the time of first operation. EGFR and PTEN showed normal expression in only one tumor but also in this case, EGFR was overexpressed and PTEN was down-regulated in the tissue of the recurrence. Otherwise, EGFR mRNA was over-represented in all samples and PTEN was down-regulated in all but one recurrent tumor tissue. These results are shown in Table 4.

Analyses of gene expressions and clinico-pathological data

Thorough statistical analyses of the studied expression levels we found that in SV1 positive samples the PTEN expressions showed significantly increased levels compared to SV1 negative cases.

For further analysis, we divided the patient into two groups. Group 1 included 15 patients who were operated at clinical diagnosis, without previous treatment. Group 2 included 8 patients where the recurrent tumor was sampled after chemo-irradiation. Four patients were present in both groups as operated and later reoperated cases. In Group 1, patients with GHRH negative tumors had significantly decreased overall survival (OS). This decrease remained significant even in the presence of SV1 positivity (Fig. 2), which showed connection with higher median levels of PTEN. In Group 2, we did not find these correlations.

Analysis of OS in the two groups together is questionable because the overlapping four patients showed that the therapy and tumor progression might lead to changed genetic profile. However, analysis of OS in the combined two groups (excluding the four overlapping patients in 
Table 1 Main clinical characteristics of patients with primary GBM

\begin{tabular}{|c|c|c|c|c|c|c|c|c|c|}
\hline $\begin{array}{l}\text { Patient } \\
\text { number }\end{array}$ & Gender & Age & $\begin{array}{l}\text { Age at } \\
\text { recognition }\end{array}$ & $\begin{array}{l}\text { Survival from } \\
\text { first diagnosis } \\
\text { (day) }\end{array}$ & $\begin{array}{l}\text { Overall } \\
\text { survival } \\
\text { (day) }\end{array}$ & $\begin{array}{l}\text { Initial } \\
\text { localization }\end{array}$ & $\begin{array}{l}\text { Treatment } \\
\text { before } \\
\text { sampling }\end{array}$ & $\begin{array}{l}\text { Treatment } \\
\text { after } \\
\text { sampling }\end{array}$ & Histology \\
\hline \multicolumn{10}{|l|}{ Group 1} \\
\hline $1 \mathrm{~A}$ & $\mathrm{~F}$ & 64 & Same & 702 & Same & Left temporal & No & CI, C & GBM \\
\hline 2 & $\mathrm{~F}$ & 67 & Same & 156 & Same & Right frontal & No & No & GBM \\
\hline 3 & M & 73 & Same & 280 & Same & Left temporo-parietal & No & I & GBM \\
\hline 4 & $\mathrm{~F}$ & 66 & Same & 1738 & Same & Left frontal & No & $\mathrm{CI}, \mathrm{C}$ & GBM \\
\hline 5 & $\mathrm{~F}$ & 66 & Same & 112 & Same & Left occipital & No & CI & GBM \\
\hline 6 & $\mathrm{~F}$ & 63 & Same & 662 & Same & Right temporal & No & $\mathrm{CI}, \mathrm{C}$ & GBM \\
\hline $7 \mathrm{~A}$ & M & 51 & Same & 721 & Same & Left temporo-occipital & No & $\mathrm{CI}, \mathrm{C}$ & GBM \\
\hline $8 \mathrm{~A}$ & M & 61 & Same & 709 & Same & Left fronto-temporal & No & CI & GBM \\
\hline 9 & M & 78 & Same & 38 & Same & Left temporal & No & No & GBM \\
\hline $10 \mathrm{~A}$ & M & 52 & Same & 715 & Same & Left frontal & No & CI, C & GBM \\
\hline 11 & M & 59 & Same & 90 & Same & Left frontal & No & No & GBM \\
\hline 12 & $\mathrm{~F}$ & 60 & Same & 1231 & Same & Left temporal & No & CI & GBM \\
\hline 13 & $\mathrm{~F}$ & 44 & Same & 65 & Same & Left temporo-parietal & No & No & GBM \\
\hline 14 & $\mathrm{~F}$ & 75 & Same & 17 & Same & Left fronto-temporal & No & $\mathrm{CI}$ & GBM \\
\hline 15 & $\mathrm{~F}$ & 44 & Same & 578 & Same & Left frontal & No & No & GBM \\
\hline \multicolumn{10}{|l|}{ Group 2} \\
\hline $1 \mathrm{~B}$ & $\mathrm{~F}$ & 65 & 64 & 264 & 702 & Left temporal & CI, C & $\mathrm{C}, \mathrm{I}$ & GBM sI \\
\hline $7 \mathrm{~B}$ & M & 53 & 51 & 21 & 721 & Right cerebellar & CI, C & $\mathrm{C}$ & GBM sI \\
\hline $8 B$ & $\mathrm{~F}$ & 63 & 61 & 50 & 709 & Left parieto-occipital & $\mathrm{CI}$ & No & GBM sI \\
\hline $10 \mathrm{~B}$ & $\mathrm{M}$ & 52 & 52 & 566 & 715 & Left frontal & CI, C & Op & GBM sI \\
\hline 16 & $\mathrm{~F}$ & 37 & 37 & 196 & 364 & Left occipital & $\mathrm{Op}, \mathrm{CI}$ & Op & GBM sI \\
\hline 17 & $\mathrm{~F}$ & 74 & 72 & 276 & 1209 & Left cerebellar & Op, Op, I & No & GBM sI \\
\hline 18 & $\mathrm{M}$ & 58 & 57 & 85 & 400 & Right frontal & $\mathrm{Op}, \mathrm{Op}, \mathrm{CI}$ & No & GBM sI \\
\hline 19 & $\mathrm{~F}$ & 51 & 50 & 187 & 402 & Right fronto-temporal & CI & No & GBM sI \\
\hline
\end{tabular}

Patients were divided into two groups: Group 1 sampling at first recognition and Group 2 sampling after previous treatment. A) and B) mean the same patient

$C I$ chemo-irradiation, $I$ irradiation, $C$ temodal monotherapy, $O p$ operation, $s I$ histological sign of postirradiation changes

the second group) also revealed that the GHRH negative cases showed shorter OS, which was still significantly decreased in cases that were GHRH negative and SV1 positive (Fig. 3). Conversely, GHRH positive and SV1 negative cases showed better prognosis. EGFR and PTEN expression levels were not correlated significantly with OS. Although, the lack of postoperative treatment itself seemed to lead to shorter survival time, in these cases rapid tumor progression produced a decrease in KPS (Karnofsky Performance Score) and led to cancelation of the suitable therapy (which should have been used postoperatively).

\section{Discussion}

Despite the multiple multimodality treatment options, GB has the worst prognosis of any central nervous system tumors. To improve the survival, GHRH antagonists have been developed for the treatment of various human cancers (Schally and Varga 1999; Schally 2008; Schally and Halmos 2012). The efficacy of GHRH antagonists in experimental tumor models is due to the suppression of the pituitary GH-hepatic IGF axis and the direct blocking of binding of autocrine/paracrine GHRH to tumoral pGHRH receptor and SV1-type receptor. It was demonstrated that GHRH antagonists bind specifically and with high affinity to splice variants of the GHRH receptor present in many malignant tumors and produce direct antiproliferative effects by blocking the binding of autocrine GHRH to receptors (Halmos et al. 2000, 2002). It was also proven that a peripherally administered GHRH analog (JV-1-42) can readily penetrate into the central nervous system (i.e., pass through the blood-brain barrier) (Jaeger et al. 2005). Earlier it was shown that treatment with antagonistic 
Table 2 Expression of mRNA of GHRH ligand and its receptors (pGHRHR, SV1 and SV2) in human GB samples

\begin{tabular}{|c|c|c|c|c|}
\hline Patient number & pGHRHR & GHRH & SV1 & SV2 \\
\hline \multicolumn{5}{|l|}{ Group 1} \\
\hline $1 \mathrm{~A}$ & - & + & - & - \\
\hline 2 & - & - & - & - \\
\hline 3 & - & + & - & + \\
\hline 4 & - & + & - & - \\
\hline 5 & - & + & - & - \\
\hline 6 & - & + & - & - \\
\hline $7 \mathrm{~A}$ & - & + & - & - \\
\hline $8 \mathrm{~A}$ & - & + & + & - \\
\hline 9 & - & - & - & + \\
\hline $10 \mathrm{~A}$ & - & + & - & - \\
\hline 11 & - & - & + & - \\
\hline 12 & - & + & - & - \\
\hline 13 & - & + & - & - \\
\hline 14 & - & - & + & - \\
\hline 15 & - & - & - & - \\
\hline \multicolumn{5}{|l|}{ Group 2} \\
\hline $1 \mathrm{~B}$ & - & + & - & - \\
\hline $7 \mathrm{~B}$ & - & - & - & - \\
\hline $8 \mathrm{~B}$ & - & - & - & - \\
\hline $10 \mathrm{~B}$ & - & - & - & - \\
\hline 16 & - & + & - & - \\
\hline 17 & - & + & - & - \\
\hline 18 & - & + & - & - \\
\hline 19 & - & - & + & - \\
\hline
\end{tabular}

Group 1 sampling at first recognition and Group 2 sampling after previous treatment. A) and $\mathrm{B}$ ) mean the same patient; + expression, no expression

analogs of GHRH reduced the tumorigenicity of U-87GM human GB cells (Kiaris et al. 2000). The main splice variant receptor, SV1, is present in several tumor types (Szepeshazi et al. 2000; Busto et al. 2002a, b; Halmos et al. 2002). However, the presence of these two main functional GHRH receptors, pGHRHR and SV1, has not been investigated in human GB tissue samples. In our study, 23 samples were obtained from primary GBs resected in the course of surgery and were analyzed for the expression of GHRH and its receptors.

The EGFR/PTEN/Akt/mTOR pathway is a key signaling pathway in the development of primary glioblastomas (Kita et al. 2007). Amplification and/or over-expression of EGFR occur in the majority of primary GBs (40 and $60 \%$, respectively). PTEN inhibits cell proliferation through PIP3 and is mutated in 15-40\% of GBs, almost exclusively in primary GBs (Ohgaki et al. 2004). Although EGFR and PTEN seem to have a crucial role in gliomagenesis, their status neither predicted response to targeted
Table 3 Relative expression levels of EGFR and PTEN genes

\begin{tabular}{|c|c|c|c|c|}
\hline \multirow[t]{2}{*}{ Patient number } & \multicolumn{4}{|c|}{ Relative expression levels } \\
\hline & EGFR & $\pm \mathrm{SE}$ & PTEN & $\pm \mathrm{SE}$ \\
\hline \multicolumn{5}{|l|}{ Group 1} \\
\hline $1 \mathrm{~A}$ & 1.282 & 0.059 & 0.682 & 0.023 \\
\hline 2 & $36.314 \uparrow$ & 0.464 & $0.424 \downarrow$ & 0.084 \\
\hline 3 & 0.837 & 0.057 & $0.139 \downarrow$ & 0.004 \\
\hline 4 & $0.112 \downarrow$ & 0.005 & $0.076 \downarrow$ & 0.001 \\
\hline 5 & $3.279 \uparrow$ & 0.086 & $0.108 \downarrow$ & 0.006 \\
\hline 6 & $0.356 \downarrow$ & 0.028 & $0.371 \downarrow$ & 0.011 \\
\hline $7 \mathrm{~A}$ & $7.864 \uparrow$ & 0.365 & $0.246 \downarrow$ & 0.021 \\
\hline $8 \mathrm{~A}$ & $143.479 \uparrow$ & 7.816 & $0.442 \downarrow$ & 0.014 \\
\hline 9 & $11.743 \uparrow$ & 0.772 & $0.150 \downarrow$ & 0.021 \\
\hline $10 \mathrm{~A}$ & 1.248 & 0.032 & $0.165 \downarrow$ & 0.007 \\
\hline 11 & 1.238 & 0.077 & $0.410 \downarrow$ & 0.230 \\
\hline 12 & 0.764 & 0.048 & $0.062 \downarrow$ & 0.002 \\
\hline 13 & $2.468 \uparrow$ & 0.281 & $0.019 \downarrow$ & 0.001 \\
\hline 14 & $4.039 \uparrow$ & 0.355 & 0.568 & 0.063 \\
\hline 15 & $5.312 \uparrow$ & 0.096 & $0.211 \downarrow$ & 0.020 \\
\hline \multicolumn{5}{|l|}{ Group 2} \\
\hline 1B & $2.084 \uparrow$ & 0.048 & $0.395 \downarrow$ & 0.005 \\
\hline $7 \mathrm{~B}$ & $3.177 \uparrow$ & 0.122 & $0.417 \downarrow$ & 0.041 \\
\hline $8 \mathrm{~B}$ & $16.380 \uparrow$ & 0.057 & $0.171 \downarrow$ & 0.021 \\
\hline 10B & $66.439 \uparrow$ & 0.691 & 1.772 & 0.043 \\
\hline 16 & $2.620 \uparrow$ & 0.054 & 1.466 & 0.048 \\
\hline 17 & $4.876 \uparrow$ & 0.068 & 0.914 & 0.019 \\
\hline 18 & $5.493 \uparrow$ & 0.213 & $0.189 \downarrow$ & 0.011 \\
\hline 19 & $0.342 \downarrow$ & 0.012 & $0.248 \downarrow$ & 0.039 \\
\hline
\end{tabular}

GAPDH normalized levels correlated with averages of peritumoral tissues (fold change level). More than twofold change in the gene expression levels was considered as gene down-/up-regulation indicated by down or up arrows, respectively. Group 1 sampling at first recognition and Group 2 sampling after previous treatment. A) and B) mean the same patient

Table 4 Expression profiles of samples with recurrent tumors

\begin{tabular}{llllll}
\hline Patient number & pGHRHR & GHRH & SV1 & EGFR & PTEN \\
\hline 1A & - & + & + & $\uparrow$ & $\downarrow$ \\
1B & - & - & - & $\uparrow$ & $\downarrow$ \\
$7 \mathrm{~A}$ & - & + & - & No change & No change \\
$7 \mathrm{~B}$ & - & + & - & $\uparrow$ & $\downarrow$ \\
$8 \mathrm{~A}$ & - & + & - & $\uparrow$ & $\downarrow$ \\
$8 \mathrm{~B}$ & - & - & - & $\uparrow$ & $\downarrow$ \\
$10 \mathrm{~A}$ & - & + & - & $\uparrow$ & $\downarrow$ \\
$10 \mathrm{~B}$ & - & - & - & $\uparrow$ & No change \\
\hline
\end{tabular}

A) samples from first operations, B) samples from recurrent tumors, $\uparrow$ over-expression, $\downarrow$ down-regulation by real-time RT-PCR

therapies like everolimus and gefitinib nor it could be correlated with survival (Kreisl et al. 2009; Ang et al. 2010). However, coexpression of EGFRv3 and PTEN in GB 

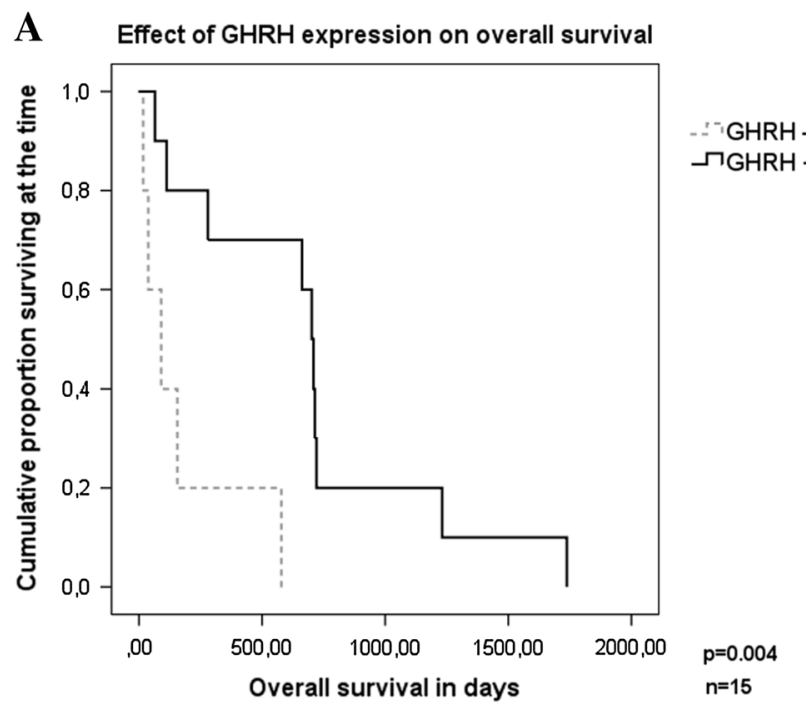

Fig. 2 Correlation between expression of mRNA of GHRH ligand and receptor SV1 and overall survival of the patients with newly diagnosed GB. a Correlation between GHRH expression and overall survival of the patients with newly diagnosed GB. Gray, dashed curve shows GHRH negative patients' survival analysis; black, continuous curve represents GHRH positive cases $(p=0.004)$. b Correlation between GHRH and SV1 expressions and overall survival



of the patients with newly diagnosed GB. Gray, dashed curve shows GHRH negative, SV1 positive patients' survival analysis; black dashed curve shows GHRH negative SV1 negative cases, gray continuous curve GHRH positive, SV1 positive cases; black, continuous curve represents GHRH positive, SV1 negative cases. $(p=0.008)$ Kaplan-Meier and log rank (Mantel-Cox) regression tests were used for survival analysis

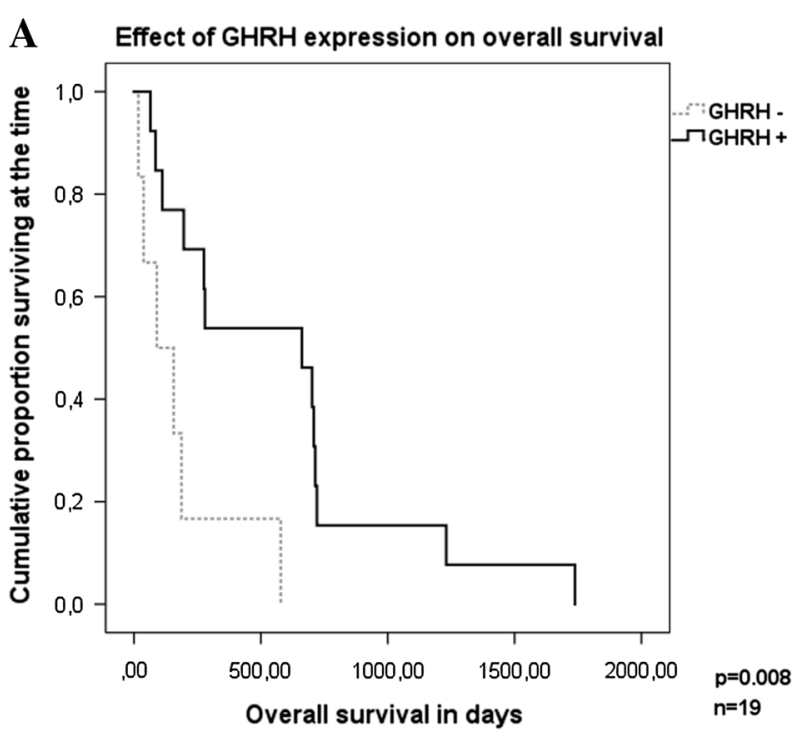

Fig. 3 Correlation between expression of mRNA of GHRH ligand and receptor SV1 and overall survival of the patients with newly diagnosed GBs and recurrent GBs together. a Correlation between GHRH expression and overall survival of the patients with newly diagnosed GBs and recurrent GBs together (Group 1 and Group 2). Gray, dashed curve shows GHRH negative; black continuous curve represents GHRH positive cases $(p=0.008)$. b Correlation between GHRH and SV1 expression and overall survival of the patients with

cells was associated with responsiveness to EGFR kinase inhibitors (Mellinghoff et al. 2005). In our study, we also evaluated classical GB markers such as EGFR and PTEN.

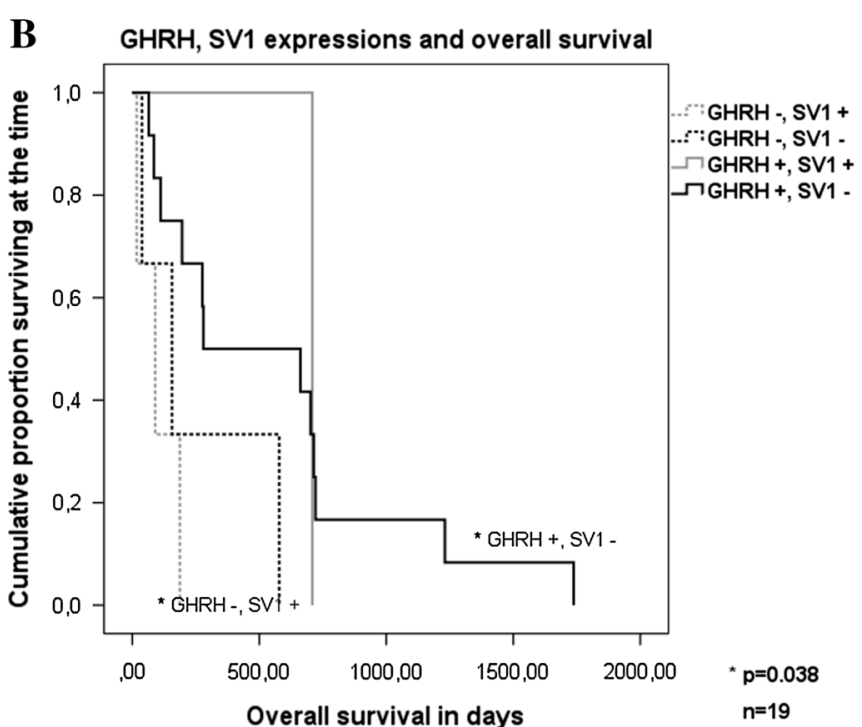

newly diagnosed GBs and recurrent GBs together (Group 1 and Group 2). Gray, dashed curve shows GHRH negative, SV1 positive patients' survival analysis; black dashed curve shows GHRH negative SV1 negative cases, gray continuous curve GHRH positive, SV1 positive cases; black, continuous curve represents GHRH positive, SV1 negative cases. $(p=0.038)$. Kaplan-Meier and log rank (MantelCox) regression tests were used for survival analysis

Moreover, as the antiproliferative effect of GHRH antagonists was proven to act through the EGFR-Akt pathway in breast cancer cells (Seitz et al. 2008), we looked for any 
correlation between GHRH or its receptors and EGFR, PTEN.

According to our results, pituitary-type GHRH receptor was not expressed in our sample set but SV1 could be detected in $17.4 \%$ of the tissues. Moreover, in SV1 positive cases, the PTEN expression levels significantly increased. The expression of GHRH was also determined and found to be positive in $61.9 \%$ of the samples which suggests that GHRH has a role in the pathogenesis of GB. This is supported by previous studies, which reported improved cell survival of cardiac (Granata et al. 2009) or tumoral cells (Pozsgai et al. 2010) following treatment with GHRH.

Substantial statistical analysis of clinico-pathological data revealed a significantly negative correlation between prognoses and the lack of GHRH expression, and this remained significant if SV1 were also expressed. Conversely, GHRH positive, SV1 negative cases showed better OS. It is partly supported by Farkas et al. (2012) who previously showed that the expression of GHRH-R was correlated with a poor response of rectal cancers to chemotherapy (Farkas et al. 2012).

This finding also suggests that not only paracrine and autocrine GHRH release could play a role in tumor progression through SV1 receptor activation and not only local intratumoral regulating factors may decrease the expression of tumoral GHRH. The tumorous GHRH expression, i.e., autocrine release of GHRH might be under influence of negative feedback effect. This effect may be based on down-regulation of GHRH expression through SV1 or other receptors mediated by systemic GHRH or other ligand. GHRH may signal through another receptor than SV1 and it could be protective. One of the presumed receptors that could mediate the responses to GHRH might be receptors for VIP (vasoactive intestinal peptide), and these receptors might be protective as in the case of inhibitory effects of VIP on the growth of lung cancer (Maruno et al. 1998). Renal cell carcinoma was also reported by Vacas et al. (2012) to be inhibited by VIP and PACAP (pituitary adenylate cyclase-activating peptide) (Vacas et al. 2012).

Our study thus provides the first evidence that GHRH and SV1 are present in a substantial part of human GB tissues and support the merit of further investigation of GHRH pathway in this malignancy. Moreover, our result showed that GHRH and SV1 expression pattern of GB samples have significant correlation with overall survival.

Acknowledgments This work was supported by the TAMOP 4.2.2.A-11/1/KONV-2012-0025 (G.H.) and TAMOP 4.2.2.A-11/1/ KONV-2012-0031 projects. The project is co-financed by the European Union and the European Social Fund.

Conflict of interest Authors declare that there is no conflict of interest that could be perceived as prejudicing the impartiality of this research.

\section{References}

Ang C, Guiot MC, Ramanakumar AV, Roberge D, Kavan P (2010) Clinical significance of molecular biomarkers in glioblastoma. Can J Neurol Sci 37(5):625-630

Busto R, Schally AV, Braczkowski R, Plonowski A, Krupa M, Groot K, Armatis P, Varga JL (2002a) Expression of mRNA for growth hormone-releasing hormone and splice variants of GHRH receptors in human malignant bone tumors. Regul Pept 108:47-53

Busto R, Schally AV, Varga JL, Garcia-Fernandez MO, Groot K, Armatis P, Szepeshazi K (2002b) The expression of growth hormone-releasing hormone (GHRH) and splice variants of its receptor in human gastroenteropancreatic carcinomas. Proc Natl Acad Sci USA 99:11866-11871

Cancer Genome Atlas Research Network (2008) Comprehensive genomic characterization defines human glioblastoma genes and core pathways. Nature 455(7216):1061-1068

Farkas R, Pozsgai E, Schally AV, Szigeti A, Szigeti E, Laszlo Z, Papp A, Gomori E, Mangel L, Horvath PO et al (2012) Possible predictors of histopathological response to neoadjuvant chemoradiotherapy for rectal cancer. J Cancer Res Clin Oncol 138(3):387-395

Granata R, Trovato L, Gallo MP, Destefanis S, Settanni F, Scarlatti F, Brero A, Ramella R, Volante M, Isgaard J et al (2009) Growth hormone-releasing hormone promotes survival of cardiac myocytes in vitro and protects against ischaemia-reperfusion injury in rat heart. Cardiovasc Res 83(2):303-312

Halmos G, Schally AV, Varga JL, Plonowski A, Rekasi Z, Czompoly $\mathrm{T}$ (2000) Human renal cell carcinoma expresses distinct binding sites for growth hormone-releasing hormone. Proc Natl Acad Sci USA 97(19):10555-10560

Halmos G, Schally AV, Czompoly T, Krupa M, Varga JL, Rekasi Z (2002) Expression of growth hormone-releasing hormone and its receptor splice variants in human prostate cancer. J Clin Endocrinol Metab 87(10):4707-4714

Havt A, Schally AV, Halmos G, Varga JL, Toller GL, Horvath JE, Szepeshazi K, Köster F, Kovitz K, Groot K et al (2005) The expression of the pituitary growth hormone-releasing hormone receptor and its splice variants in normal and neoplastic human tissues. Proc Natl Acad Sci USA 102(48):17424-17429

Jaeger LB, Banks WA, Varga JL, Schally AV (2005) Antagonists of growth hormone-releasing hormone cross the blood-brain barrier: a potential applicability to treatment of brain tumors. Proc Natl Acad Sci USA 102(35):12495-12500

Jaszberenyi M, Schally AV, Block NL, Zarandi M, Cai RZ, Vidaurre I, Szalontay L, Jayakumar AR, Rick FG (2013) Suppression of the proliferation of human U-87 MG glioblastoma cells by new antagonists of growth hormone. Releasing hormone in vivo and in vitro. Target Oncol 8(4):281-290. doi:10.1007/ s11523-013-0264-y

Kiaris H, Schally AV, Varga JL (2000) Antagonists of growth hormone-releasing hormone inhibit the growth of U-87MG human glioblastoma in nude mice. Neoplasia 2(3):242-250

Kita D, Yonekawa Y, Weller M, Ohgaki H (2007) PI3KCA alterations in primary (de novo) and secondary glioblastomas. Acta Neuropathol Berlin 113:295-302

Knobbe CB, Merlo A, Reifenberger G (2002) PTEN signaling in gliomas. Neuro Oncol J 4(3):196-211

Kreisl TN, Lassman AB, Mischel PS, Rosen N, Scher HI, TeruyaFeldstein J, Shaffer D, Lis E, Abrey LE (2009) A pilot study of everolimus and gefitinib in the treatment of recurrent glioblastoma (GBM). J Neurooncol 92(1):99-105

Li J, Yen C, Liaw D, Podsypanina K, Bose S, Wang SI, Puc J, Miliaresis C, Rodgers L, McCombie R et al (1997) PTEN, a putative protein tyrosine phosphatase gene mutated in human brain, breast, and prostate cancer. Science 275(5308):1943-1947 
Livak KJ, Schmittgen TD (2001) Analysis of relative gene expression data using real-time quantitative PCR and the 2(-Delta Delta C(T)) Method. Methods 25(4):402-408

Louis DN, Ohgaki H, Wiestler OD, Cavenee WK, Burger PC, Jouvet A, Scheithauer BW, Kleihues P (2007) The 2007 WHO classification of tumours of the central nervous system. Acta Neuropathologica 114(2):97-109. Erratum in: Acta Neuropathologica 114(5):547

Maruno K, Absood A, Said SI (1998) Vasoactive intestinal peptide inhibits human small-cell lung cancer proliferation in vitro and in vivo. Proc Natl Acad Sci USA24;95(24):14373-14378

Mellinghoff IK, Wang MY, Vivanco I, Haas-Kogan DA, Zhu S, Dia EQ et al (2005) Molecular determinants of the response of glioblastomas to EGFR kinase inhibitors. N Engl J Med 353:2012-2024

Ohgaki H, Dessen P, Jourde B, Horstmann S, Nishikawa T, Di Patre PL, Burkhard C, Schüler D, Probst-Hensch NM, Maiorka PC (2004) Genetic pathways to glioblastoma: a population-based study. Cancer Res 64(19):6892-6899

Øvstebø R, Haug KB, Lande K, Kierulf P (2003) PCR-based Calibration Curves for Studies of Quantitative Gene Expression in Human Monocytes: development and Evaluation. Clin Chem 49(3):425-432

Pozsgai E, Schally AV, Zarandi M, Varga JL, Vidaurre I, Bellyei S (2010) The effect of GHRH antagonists on human glioblastomas and their mechanism of action. Int J Cancer 127(10):2313-2322

Rozen S, Skaletsky H (2000) Primer3 on the WWW for general users and for biologist programmers. In: Misener S, Totowa NJ (eds) Krawetz S. Methods in Molecular Biology, Humana Press, Bioinformatics Methods and Protocols, pp 365-386

Schally AV (2008) New approaches to the therapy of various tumors based on peptide analogues. Horm Metab Res 40:315-322

Schally AV, Halmos G (2012) Targeting to Peptide Receptors. In: Kratz F, Senter P, Steinhagen H (eds) Drug Delivery in Oncology: From Basic Research to Cancer Therapy. Wiley-VCH, Weinheim, pp 1219-1262

Schally AV, Varga JL (1999) Antagonistic analogs of growth hormone-releasing hormone: new potential antitumor agents. Trends Endocrinol Metab 10:383-391

Schally AV, Varga JL (2006) Antagonists of growth hormone-releasing hormone in oncology. Comb Chem High Throughput Screening 9(3):163-170
Schally AV, Varga JL, Engel JB (2008) Antagonists of growth hormone-releasing hormone: an emerging new therapy for cancer. Nat Clin Pract Endocrinol Metab 4:33-43

Seitz S, Hohla F, Schally AV, Moder A, Engel JB, Horn F, Varga J, Zarandi M, Ortmann O, Köster F, Buchholz S (2008) Inhibition of estrogen receptor positive and negative breast cancer cell lines with a growth hormone-releasing hormone antagonist. Oncol Rep 20(5):1289-1294

Steck PA, Pershouse MA, Jasser SA, Yung WK, Lin H, Ligon AH, Langford LA, Baumgard ML, Hattier T, Davis T et al (1997) Identification of a candidate tumour suppressor gene, MMAC1, at chromosome $10 \mathrm{q} 23.3$ that is mutated in multiple advanced cancers. Nat Genet 15(4):356-362

Stupp R, Mason WP, van den Bent MJ, Weller M, Fisher B, Taphoorn MJ, Belanger K, Brandes AA, Marosi C, Bogdahn U et al (2005) Radiotherapy plus concomitant and adjuvant temozolomide for glioblastoma. European Organisation for Research and Treatment of Cancer Brain Tumor and Radiotherapy Groups; National Cancer Institute of Canada Clinical Trials Group. N Engl J Med 352(10):987-996

Szepeshazi K, Schally AV, Groot K, Armatis P, Hebert F, Halmos G (2000) Antagonists of growth hormone-releasing hormone (GH-RH) inhibit in vivo proliferation of experimental pancreatic cancers and decrease IGF-II levels in tumours. Eur J Cancer 36:128-136

Vacas E, Fernández-Martínez AB, Bajo AM, Sánchez-Chapado M, Schally AV, Prieto JC, Carmena MJ (2012) Vasoactive intestinal peptide (VIP) inhibits human renal cell carcinoma proliferation. Biochim Biophys Acta 1823(10):1676-1685

Weller M, Felsberg J, Hartmann C, Berger H, Steinbach JP, Schramm J, Westphal M, Schackert G, Simon M, Tonn JC, Heese O, Krex D, Nikkhah G, Pietsch T, Wiestler O, Reifenberger G, von Deimling A, Loeffler M (2009) Molecular predictors of progressionfree and overall survival in patients with newly diagnosed glioblastoma: a prospective translational study of the German Glioma Network. J Clin Oncol 27(34):5743-5750

Zhu H, Acquaviva J, Ramachandran P, Boskovitz A, Woolfenden S, Pfannl R, Bronson RT, Chen JW, Weissleder R, Housman DE et al (2009) Oncogenic EGFR signaling cooperates with loss of tumor suppressor gene functions in gliomagenesis. Proc Natl Acad Sci USA 106(8):2712-2716 